\title{
水車の羽根高さと回転数の違いが 堰上げに及ぼす影響のMPS法による評価 EFFECT OF RUNNER DEPTH AND ROTATION SPEED OF WATER WHEEL ON BACK WATER BY MPS METHOD
}

\author{
浪平 篤 1 高木強治 ${ }^{2} \cdot$ 後藤眞宏 1 \\ Atsushi NAMIHIRA, Kyoji TAKAKI and Masahiro GOTO \\ 1正会員 博士 (農) 農研機構農村工学研究所資源循環工学研究領域（テ305-8609 つくば市観音台2-1-6） \\ 2正会員 博士(農) 農研機構農村工学研究所水利工学研究領域 （ 同 上
}

\begin{abstract}
The applicability of MPS method with a modified model for non-uniform particle diameter and a method to suppress numerical pressure fluctuation, as an assessment tool for flow regimes in installing a current water wheel in an open channel as one of the development of micro-scale hydropower generation in irrigation systems, was examined. As a result, the turbulent flows around water wheel were calculated with stable condition. Furthermore, the simulated water depths at upstream side of water wheel were about $0.005 \mathrm{~m}$ larger than the experimental results, at any given runner depths and rotation speeds. This error was equal to the distance between water particles at initial arrangement, and was only $3 \%$ of water depth at the condition with no water wheel.
\end{abstract}

Key Words : micro-scale hydropower generation, irrigation channel, current water wheel, back water, MPS method

\section{1. 緒論}

昨今のエネルギー事情から再生可能エネルギーの必要 性が高まる中, 農業用用水路における小水力発電も注目 を浴びている. 用水路のうち落差工のように落差を有す る地点では，実施事例が増えつつある ${ }^{1)}{ }^{2)}$ 。一方で用水 路のうち落差のない緩勾配の開水路部分では，流れのエ ネルギーの抽出は容易でないため, 現地試験は散見され るものの ${ }^{3)}$, 4)，普及には至っていない．開水路部分は用 水路の大部分を占めることから，今後はこのような箇所 での実施への要望が高まると考えられる.

開水路部分で小水力発電を行うためには，水車自体も しくは付帯施設の設置によって水車の上流側で堰上げを 生じさせ，水車の上下流のエネルギ一差を高めることが 必要となる。 それに対し, 用水路の余裕高 ${ }^{5)}$ は建設時の 経済性から必要最低限に設計されていることが多く，堰 上げが過剰であれば水路で溢水が生じる可能性がある. 従って, 開水路部分で小水力発電を行うためには，水車 の設置によって生じる堰上げの評価が不可欠である.

前報)では，水車設置による堰上げの評価方法として， 自由水面の大変形, 水滴の飛沫, 気泡の混入を伴う流れ
を安定して解析できるMPS法7 に着目し，用水路のうち 開水路部分に設置される代表的な水車の一つである流し 掛け水車の模型実験結果 ${ }^{8)}$ の再現を試みた. その結果, MPS法はこれまでに適用性が確認されている種々の水理 構造物の周辺の流れ ${ }^{9}$ や, 大気中に射出される水流に よって回転するペルトン水車のバケット内流れ ${ }^{10),}{ }^{11)}$ に 加えて，水車の設置が開水路の流れに及ぼす影響につい ても定性的な傾向を捉えられることが確認された。 しか しながら，MPS法に特有の圧力の擾乱を抑えるための手 法を導入していなかったこと, 鉛直2次元解析を行った こと，単相流解析を行ったこと等の課題により，定量的 には十分な再現性が得られなかった。また，瞬間的かつ 局所的に大きな流速が発生する等, 解析の安定性が十分 ではなかった。

そこで本研究では，前報の解析方法における課題のう ち，計算機への負荷の増加が相対的に小さくて済むこと から，圧力の擾乱を抑えるための手法の導入を検討する. そして，同じく流し掛け水車を対象として，羽根高さと 回転数の違いが水車設置による堰上げに及ぼす影響の評 価に対し，MPS法を用いることの妥当性を検証する. 


\section{2. 解析の方法}

\section{（1） MPS法の概要}

MPS (Moving Particle Semi-implicit) 法7) とは, 非圧縮性 流れを有限個の粒子で近似してラグランジュ的に解く方 法である. 支配方程式における微分演算子を粒子間相互 作用モデルによって表現すること，連続式として密度一 定条件を粒子数密度一定条件といいかえた式を用いるこ と等が特徴である.

用いた支配方程式は，基本的には前報6) と同一で標準 型のMPS法のものである.ここでは連続式(式(1)) と粒 子数密度の評価式(式(2))のみを示す.

$$
\begin{gathered}
\frac{1}{n^{0}} \frac{D n}{\partial t}+\nabla \boldsymbol{u}=0 \\
\langle n\rangle_{i}=\sum_{i \neq j}\left\lfloor w\left(\left|\boldsymbol{r}_{j}-\boldsymbol{r}_{i}\right|, r_{e i}\right)\right\rfloor
\end{gathered}
$$

$n$ は粒子数密度， $\boldsymbol{u}$ は粒子の流速ベクトル，下付き文字 $i, j$ は粒子の番号, $\boldsymbol{r}$ は粒子の位置ベクトル, $n^{0}$ は初 期配置における $n$ であり, 密度一定条件を満足するため 一定值とされる， $r_{e i}$ は粒子 $i$ に関する粒子間相互作用の 及ぶ範囲を示す係数であり，初期配置における粒子間距 離 $l_{0}$ を基準とすると, $n$ の計算式では $2.1 l_{0}$, 勾配の粒子 間相互作用モデルでは $2.1 l_{0}$, Laplacianの同モデルでは $4.0 l_{0}$ が推奨されている. $w$ は粒子 $i, j$ 間相互作用に関 する重み関数であり, 式(3)で計算される.

$$
w\left(\left|\boldsymbol{r}_{j}-\boldsymbol{r}_{i}\right|, r_{e i}\right)=\left\{\begin{array}{lll}
\frac{r_{e_{i}}}{\left|\boldsymbol{r}_{j}-\boldsymbol{r}_{i}\right|}-1 & \text { for } & 0 \leq\left|\boldsymbol{r}_{j}-\boldsymbol{r}_{i}\right|<r_{e i} \\
0 & \text { for } & r_{e i} \leq\left|\boldsymbol{r}_{j}-\boldsymbol{r}_{i}\right|
\end{array}\right.
$$

\section{（2）非均一粒子径モデル}

水車の羽根はその両面で水と接する薄肉構造物である ことから，前報6) と同様に，非均一粒子径モデル`辛適 用して，羽根を構成する粒子については， $l_{0}$ すなわち粒 子径を他の粒子よりも小さくした，併せて，壁境界で粒 子を3層配置するのに倣い，羽根の厚さ方向には粒子を4 層配置するとともに，羽根のうち最も外側の粒子のみを $n$ と圧力の計算対象とした. このとき, 羽根を挟むよう に存在する水粒子に対しては，互いを粒子間相互作用モ デルの適用対象から外す処理を行った．羽根の外側のあ る面を構成する粒子と, それと向か心合う面に隣接する 水粒子に対しても，同様の処理を行った. なお, これら の処理を行っても, 羽根近傍の水粒子と羽根から離れた 水粒子とで， $n$ に明確な差は生じなかった。

非均一粒子径モデルは，nの計算式と，勾配および Laplacianの粒子間相互作用モデルに対して構築されてい る ${ }^{7)}$.これらの計算式およびモデルに含まれる係数には, $n^{0}$ と, 統計的な分散の増加を解析解と一致させるため に導入される入がある．標準型MPS法のような単一粒子
径モデルでは，初期粒子配置において十分に内部の粒子 を対象に， $n^{0}$ は式(2)から，入は式(4)から計算される.

$$
\lambda_{i}=\frac{\left.\sum_{i \neq j}|| \boldsymbol{r}_{j}-\left.\boldsymbol{r}_{i}\right|^{2} w\left(\left|\boldsymbol{r}_{j}-\boldsymbol{r}_{i}\right|, r_{e i}\right)\right]}{\sum_{i \neq j}\left[w\left(\left|\boldsymbol{r}_{j}-\boldsymbol{r}_{i}\right|, r_{e i}\right)\right]}
$$

非均一粒子径モデルでは， $n^{0}$ は式(5)から計算され， $\lambda$ は $n^{0}$ との積としてのみ使用されることから，その積を 一つの係数とした式(6)の $\Lambda$ が用いられる.

$$
\begin{aligned}
& \langle n\rangle_{i}=\sum_{i \neq j}\left[\frac{V_{j} w\left(\left|\boldsymbol{r}_{j}-\boldsymbol{r}_{i}\right|, r_{e i}\right)+V_{i} w\left(\left|\boldsymbol{r}_{j}-\boldsymbol{r}_{i}\right|, r_{e j}\right)}{2 V_{i}}\right] \\
& \Lambda_{i}=\sum_{i \neq j}\left[\left|\boldsymbol{r}_{j}-\boldsymbol{r}_{i}\right|^{2} \frac{V_{j} w\left(\left|\boldsymbol{r}_{j}-\boldsymbol{r}_{i}\right|, r_{e i}\right)+V_{i} w\left(\left|\boldsymbol{r}_{j}-\boldsymbol{r}_{i}\right|, r_{e j}\right)}{2 V_{i}}\right]
\end{aligned}
$$

$d$ は次元数, $V$ は $l_{0}{ }^{d}$ である. なお, 式(3)は非均一粒子 径モデルにそのまま適用できる.

本研究のように $r_{e i}$ の範囲内で異なる径の粒子の存在 比率が時々刻々変化する状況で非均一粒子径モデルを適 用する場合， $n^{0}$ と $\Lambda$ の計算において，どのような粒子 を対象とすべきか推奨されていない，そこで本研究では， 単一粒子径モデルと同じく, 初期粒子配置において十分 に内部の水粒子を対象に計算することとした. 前報でも 同様としていたが，後述の圧力の擾乱を抑えるための手 法を導入していないことから，その妥当性の検証には至 らなかったため, 本研究でそれを行う.

\section{（3）圧力の擾乱を抑えるための方法}

本研究では，MPS法に特有の圧力の擾乱を抑えるため の手法を新たに導入した.この手法に関する研究は近年 多く，大きな成果を上げているものには，対称型の圧力 勾配項の導入によって運動量の保存性を向上させる方法 (CMPS法)，圧力のPoisson方程式の生成項を，標準型 MPS法で用いられる粒子数密度の偏差ではなく, 周囲粒 子の相対的な移動情報を用いて評価することで, 高精度 化する方法 (HS), 圧力のPoisson方程式のLaplacianに標 準型MPS法よりも高次の粒子間相互作用モデルを適用す る方法(HL) 等がある ${ }^{12)}$ 。これらの方法が組合せて適用 されれば，圧力の擾乱はより効果的に低減される ${ }^{13), 14)}$ その他に, HS と同様に圧力のPoisson方程式の生成項 に着目し，その定式化を再検討した方法(以下，近藤・ 越塚 ${ }^{15)}$ の方法)もある. その具体的な内容は, 以下のと おりである．まずその前提として標準型MPS法では，連 続式(式(1))から導出された式(7)のPoisson方程式が用い られる。

$$
\nabla^{2} p^{k+1}=\frac{\rho}{\Delta t^{2}} \frac{n^{*}-n^{0}}{n^{0}}
$$

ここで, $p$ は圧力, $\rho$ は流体の密度, $\Delta t$ は計算時間刻 み，上付き文字 $k$ は時間ステップを表し， $n^{*}$ は時間ス テップ $k$ のうち陽的な計算のみが終了した時点の $n$ であ 


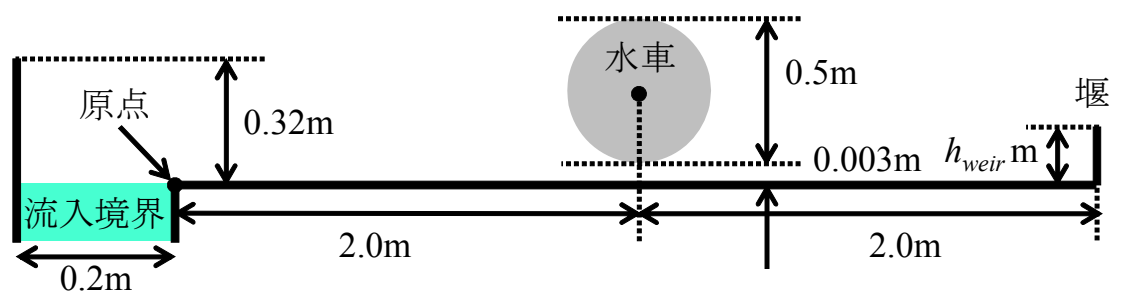

(a) 全体

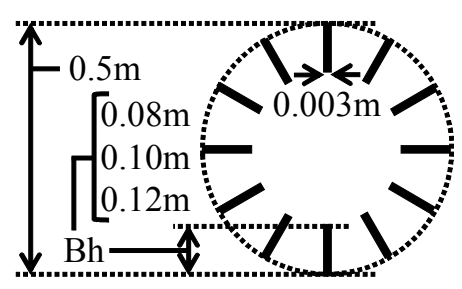

(b) 水車のみ

図-1 解析モデルの概念図

る.これに対し近藤・越塚の方法では，このPoisson方程 式の生成項(式(7)の右辺)を, 式(8)のように, 階数の異 なる3つの時間差分の項に分解寸る.

(生成項)

$$
\begin{aligned}
& =\frac{\rho}{\Delta t^{2}} \frac{n^{*}-2 n^{k}+n^{k-1}}{n^{0}}+\frac{\rho}{\Delta t^{2}} \frac{n^{k}-n^{k-1}}{n^{0}}+\frac{\rho}{\Delta t^{2}} \frac{n^{k}-n^{0}}{n^{0}} \\
& =S_{2}+S_{1}+S_{0}
\end{aligned}
$$

さらに, 式(9)のように係数 $\alpha, \beta, \gamma$ を導入する.

$$
(\text { 生成項 })=\alpha S_{2}+\beta S_{1}+\gamma S_{0}
$$

これらの係数を適切な值に設定することで，圧力振動を 抑制するのである，それらの最適值は，静水圧とダムブ レイクの解析から，それぞれ0.96，0.096，0.00096であ ることが確認されている。このような設定により式(7) が満足されなくなるが，標準型MPS法でも $\alpha, \beta, \gamma$ の 全てを 0.2 とするのと同等のLaplacianの緩和が行われる場

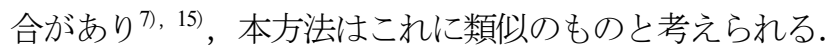

なお，近藤・越塚の方法では，式(9)の導入に加えて, 自由水面の境界条件に用いられる自由水面上に存在する 粒子の判定式(式(10))

$$
\langle n\rangle_{i}<c n^{0}
$$

において, 標淮型MPS法では $c=0.95 \sim 0.97$ が推奨されて いる7のに対し， $c=0.80$ を採用している. さらに，許容 される粒子同士の接近距離として, 標準型MPS法では $l_{0}$ の0.5倍としている7のに対し，0.7倍を採用している.

本研究では, 非均一粒子径モデルの導入によって標準 型MPS法と比較して計算がかなり煩雑になっていること を考慮して, 圧力の擾乱を抑えるための各手法のうち, 比較的簡易でありながら一定の効果を期待できる近藤・ 越塚の方法を採用寸ることとした，なお，近藤・越塚の 方法に更なる検討を加え, より安定した解析を可能とし た報告 ${ }^{16)}$ もるが，近藤・越塚の方法において静水圧の 理論值との一致状況から決定された $\alpha=0.96 か ゙$ 使用され ず $\alpha=1.0$ としていること, 安定性は大幅には改善されて いないことから，ここでは採用しなかった。

また，MPS法は前述のように非圧縮性流れを対象とし ているが，標淮型では僅かな圧縮性の付与によって数值 的な安定性が改善されることが報告されている7゙. 前報
に引き続き, 本研究でもこの方法も採用した. しかし, 予備計算において, この方法の有無が解析結果に及ぼす 影響を調べたところ，明確な差は確認されなかった。 こ のことは, 近藤・越塚の方法の影響と考えられる.

\section{（4）解析モデル}

解析モデルは，前報の と同様，詳細なデータが計測さ れている流し掛け水車の模型実験8 を模擬して作成した. 流し掛け水車とは, 落差のない開水路に堰やゲート等を 伴わずに設置され，水車自体によってその上流側で堰上 げを生じさせる水車をいう ${ }^{177}$. 解析モデルの対象範囲は, 計算機の能力上の制限加, 水車の中心から上下流に $2 \mathrm{~m}$ の地点の間とした (図-1 (a)). また, 模型水路と水車 の幅はそれぞれ0.240m，0.236mでほぼ同一であること8), および，実験状況の映像を確認したところ，縦断面にお ける流れが卓越していると考えられたことから，鉛直2 次元解析を行った. 水車の羽根の高さBhには, 0.08 , $0.10 ， 0.12 \mathrm{~m}$ のタイプを対象とした (図-1(b))， $l_{0}$ につ いては, 水車の羽根では羽根の厚さの $1 / 4$ である $0.00075 \mathrm{~m}$ ，その他では $0.005 \mathrm{~m}$ とた.

\section{(5) 解析の条件}

水理条件には，実験結果 ${ }^{8)}$ が比較的多いことから，流 量 $0.016 \mathrm{~m}^{3} / \mathrm{s}$, 水車を設置しない状態の水深 $h_{0} 0.16 \mathrm{~m}$, 同 状態のフルード数 0.35 を採用した. なお， $h_{0}$ については, 後述 (3.（2)) 寸る水車を設置した状態における水車上 流側水深と同じく, 水車の中心(図-1 (a)) から上流に $1 \mathrm{~m}$ の地点で評価した. 上記の状態を再現するため, 水車を 設置しない状態での解析を行い, 水路末端の堰の高さ $h_{\text {weir }}$ (図-1 (a))を試行錯誤で調整した.

流入境界 (図-1 (a)) には可溶性移動壁 18 を用い, 解析 モデルの末端の堰の直下流では自由流出境界とした.

水車の回転数 $\mathrm{Nr}$ にいては, 前述の水理条件下で各 $\mathrm{Bh}$ の水車を使用した模型実験8 ${ }^{8}$ における観測值の範囲の うち, ほぼ最小值, 中間值, 最大值を強制的に与えた。 具体的には, $\mathrm{Bh}=0.08 \mathrm{~m}$ のとき $\mathrm{Nr}=5,10,13 \mathrm{rpm}$, $\mathrm{Bh}=0.10 \mathrm{~m}$ のとき $\mathrm{Nr}=5,10,14 \mathrm{rpm}, \mathrm{Bh}=0.12 \mathrm{~m}$ のとき $\mathrm{Nr}=8 ， 11 ， 15 \mathrm{rpm}$ とした. ここで，模型実験では水車は 受動的に回転しており，Nrも完全に一定ではない．しか しこのような扱いは1段階難しい問題であり, まずは上 
述の単純化した現象を再現できることが必要と考え，こ のような設定とした．なお模型実験では，水車に種々の 負荷を与えることで, $\mathrm{Nr}$ の違いを表現している.

初期条件として，可溶性移動壁の他に水粒子が全く存 在しない状態を設定し，水位変動がほぼ一定の範囲内に 収まった時点以降の解析結果を, 評価の対象とした.

\section{3. 解析結果と考察}

\section{(1) 瞬間的な流況}

まず， $\mathrm{Bh}(2$ ．（4)）と，負荷すなわち $\mathrm{Nr}(2$ ．（5))の 違いが，水車の周辺の流況に及ぼす影響を調べる。羽根 の一つが水路底に対して垂直となる瞬間，および，それ から $\pi / 12 \mathrm{rad}$ 回転した瞬間の流況の一例を図-2に示寸. なお本図では，原点の位置および流れの方向を図-1 (a) と同一としており，水車は反時計回りに回転している.

図-2より，(1)同程度のNrではBhが大きいほど水車の 上流側の水深が大きくなる，(2) Nrが小さいほど水車の内 部の水面勾配が大きくなる, (3) Nrが小さいほど羽根の角 度にかかわらず水面付近で明確な主流が生じる，(4) Nrが 大きいほど主流は明確ではなくなる等の傾向がみられた。 これらの傾向は定性的ではあるが，実験結果 ${ }^{8}$ とほぼ同 様である。また，前報の解析結果6 では瞬間的かつ局所 的に大きな流速が発生していたが，圧力の擾乱を抑える ための手法を導入したことで解消されており, 解析の安 定性が大幅に向上している．但し，図-2のような局所的 な流況に対する再現性が，同手法の導入によってどの程 度向上したについては, 計測結果がないため確認できて いない，大域的な現象に対する再現性に及ぼす影響につ いては，3. (2)で確認する.

なお，実験状況の映像では，羽根が水没寸る際，大気 の一部が巻き込まれて羽根の下流側で微小な気泡となり， 羽根の回転に伴い，その気泡は羽根に沿って水面に浮上 する場合があった，一方で解析結果では，図-2のように， 同様の過程で羽根の下流側の全面に水粒子の存在しない 薄い領域が生じる場合があるものの，羽根の回転に伴い， 消滅している，前報の解析結果では，水粒子の存在しな い領域はより大きく，また水面に浮上することも消滅す ることもなかった.この点についても本研究では再現性 が改善されている. 但し, 気泡の挙動の厳密な評価には, 本研究で採用した液相のみの単相流解析ではなく, 気液 二相流解析を行う必要があるため, 今後の課題である.

また, 非均一粒子径モデルでの $n^{0}$ と $\Lambda$ の計算の対象 を，初期粒子配置において十分に内部の水粒子としたが (2. (2))，羽根近傍において，この設定が原因とみら れる圧力の擾乱の発生等は確認されなかった.

\section{（2）水車設置による堰上げ}

次に, $\mathrm{Bh}$ と $\mathrm{Nr}$ 違いが水車設置による堰上げに及ぼ
寸影響を調べる. 水車の中心から上流に $1 \mathrm{~m}$ の地点にお ける水車を設置しない状態の水深と, 同地点における水 車を設置した状態の水深の経時変化を図-3に示す．水面 の位置は，式(9)で自由水面と判定された粒子のうち, 前述の評価地点に最も近いものの上端とした. 圧力の擾 乱を抑えるための手法を導入したことで，水面形状は非 常に安定しており, 自由水面となる粒子が一意に定まら ないような状況は生じなかった，図-3より，水車を設置 した状態の水車上流側の水深は, $\mathrm{Nr}$ の減少に伴って, よ り大きく堰上げされる現象が再現された，また，その堰 上げはBhが大きいほど増大する現象が再現された。

図-3の水深の平均值から水車設置による堰上げを算出 して整理したものが図-4である. 本図には比較のため実 験結果 ${ }^{8)}$ も掲載した. 本図より, 水車設置による堰上げ の解析結果は，いずれのBhおよびNrにおいても実験結 果よりも $0.005 \mathrm{~m}$ 程度過大となった. しかしながら，この 誤差は, 水粒子の $l_{0}(2$. (4)) とほぼ同值である. 水車 を設置しない状態の水深 $0.16 \mathrm{~m}(2$ ．（5)）に対しては $3 \%$ 程度である. 前報では水車上流側の水深は実験結果より も $0.015 \mathrm{~m}$ 程度高い值のになったことと比較しても，大幅 に改善されている。 さらに，BhおよびNrにかかわらず 一定の誤差とみなせた。 これらのことから，本研究にお ける $l_{0}$ 寸なわち空間解像度では, 十分な再現結果が得ら れたと考えられる.

以上より，Bhと $\mathrm{Nr}$ の違いが水車設置による堰上げに 及ぼす影響の評価に対し，本研究で行ったMPS法による 解析を適用することは，妥当であると考えられる．今後 は, 同一の実験結果を対象として $l_{0}$ をより小さくした解 析，もしくは，同一の $l_{0}$ で規模のより大きな実験結果や 実機を対象とした解析を行い，実務設計一の適用に向け て，再現精度をさらに向上させる検討を行う必要がある.

\section{4. 結論}

本研究では, 農業用用水路のうち開水路部分に設置さ れる代表的な水車の一つである流し掛け水車に着目し， 羽根高さと回転数の違いが水車設置による堰上げに及ぼ す影響の評価に対し，非均一粒子径モデルを採用し，圧 力の擾乱を抑えるための手法を導入したMPS法を用いる ことの妥当性を検討した. 得られた結果を以下に示寸.

(1)流し掛け水車周辺の複雑な流れを安定して解析するこ とができた。

(2)水車設置による堰上げの解析結果は, 羽根高さおよび 回転数にかかわらず実験結果よりも $0.005 \mathrm{~m}$ 程度過大と なった.

(3)上記(2)の誤差は，水粒子の初期配置における粒子間 距離とほぼ同值であった，また，水車を設置しない状 態の水深に対しては $3 \%$ 程度であった。

(4)上記(2)，(3)より，採用した空間解像度では十分な再 
(a) $\mathrm{Bh}=0.08 \mathrm{~m}, \mathrm{Nr}=5 \mathrm{rpm}$
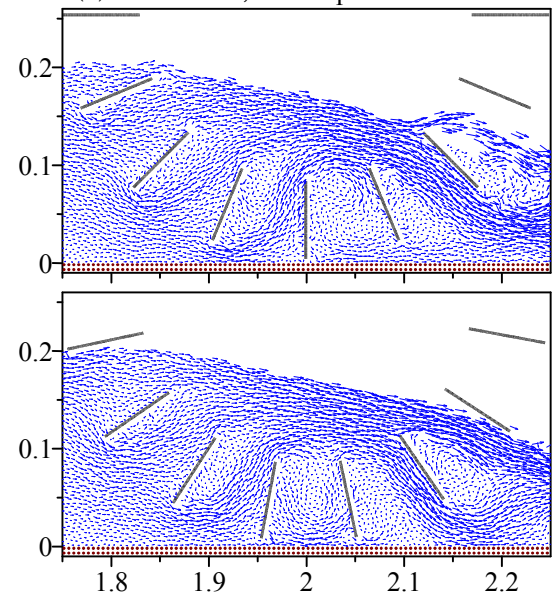

(d) $\mathrm{Bh}=0.10 \mathrm{~m}, \mathrm{Nr}=5 \mathrm{rpm}$
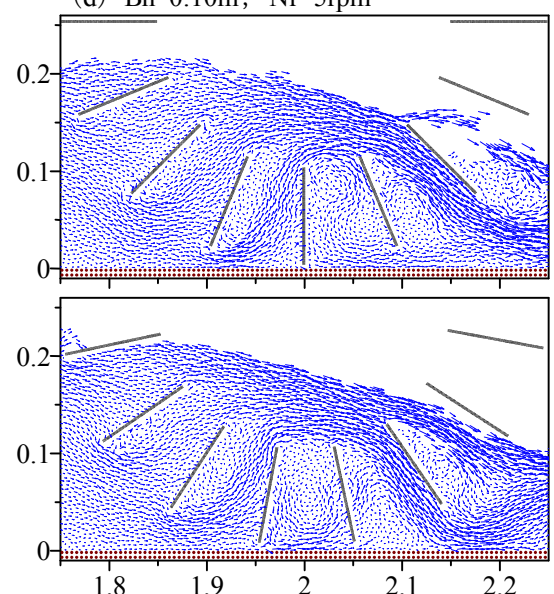

(g) $\mathrm{Bh}=0.12 \mathrm{~m}, \mathrm{Nr}=8 \mathrm{rpm}$
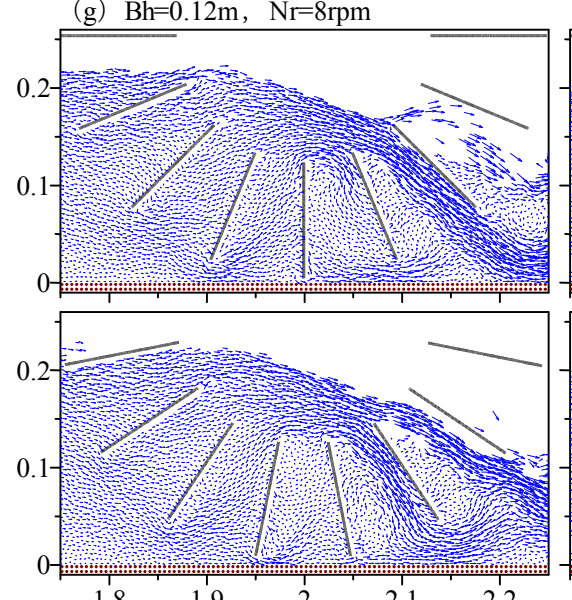

2.2 (b) $\mathrm{Bh}=0.08 \mathrm{~m}, \mathrm{Nr}=10 \mathrm{rpm}$

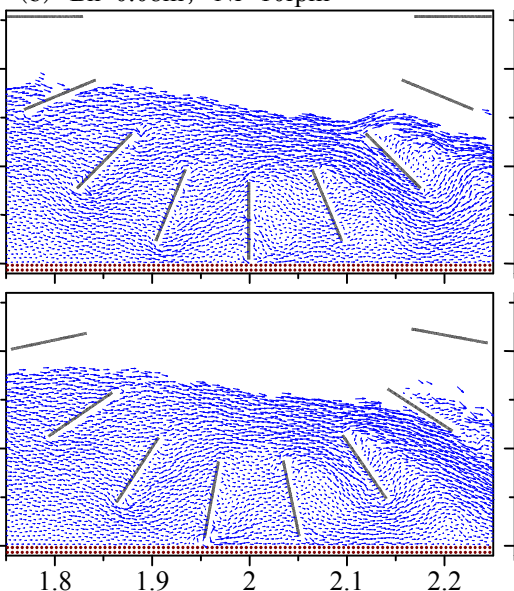

(e) $\mathrm{Bh}=0.10 \mathrm{~m}, \mathrm{Nr}=10 \mathrm{rpm}$
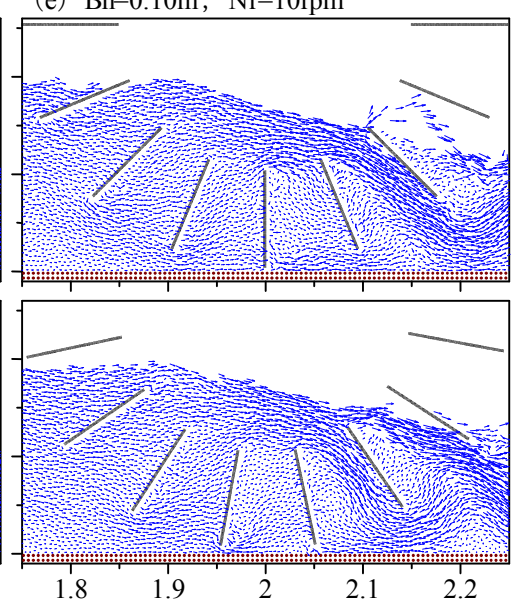

(h) $\mathrm{Bh}=0.12 \mathrm{~m}, \mathrm{Nr}=11 \mathrm{rpm}$
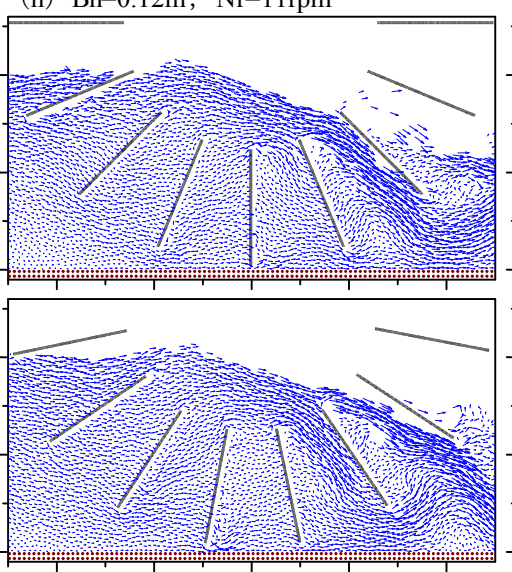

$\begin{array}{lllll}1.8 & 1.9 & 2 & 2.1 & 2.2\end{array}$

・壁粒子 ・壁粒子(水車の羽根) $-1 \mathrm{~m} / \mathrm{s}$ (c) $\mathrm{Bh}=0.08 \mathrm{~m}, \mathrm{Nr}=13 \mathrm{rpm}$
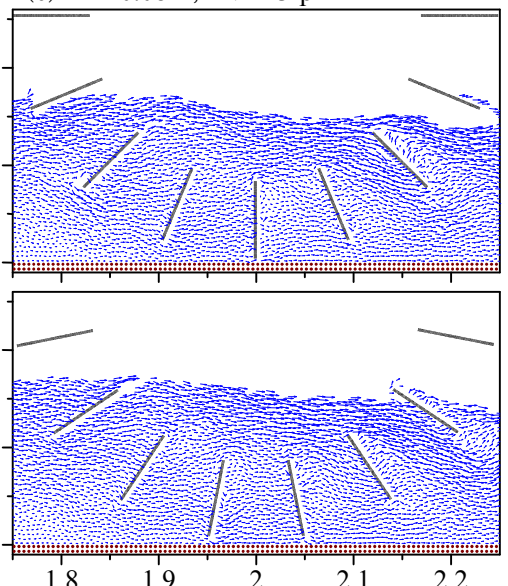

(f) $\mathrm{Bh}=0.10 \mathrm{~m}, \mathrm{Nr}=14 \mathrm{rpm}$
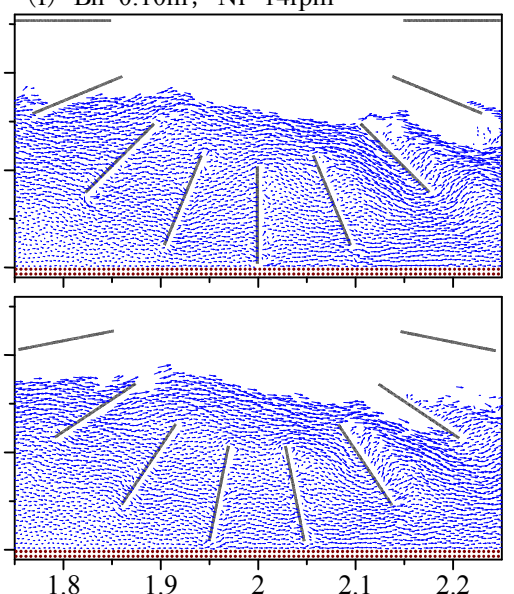

(i) $\mathrm{Bh}=0.12 \mathrm{~m}, \mathrm{Nr}=15 \mathrm{rpm}$
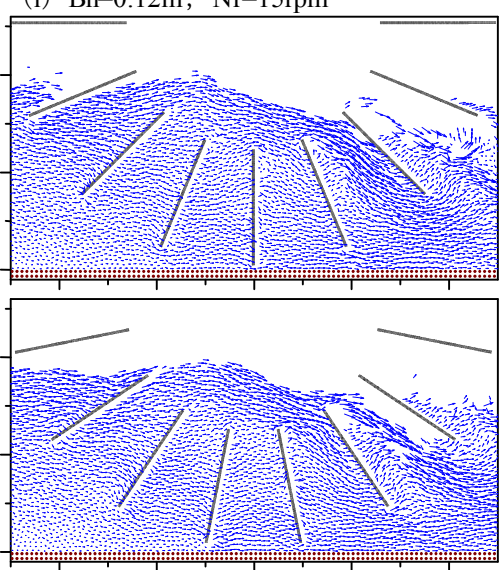

$\begin{array}{lllll}1.8 & 1.9 & 2 & 2.1 & 2.2\end{array}$

図-2 水車の羽根の一つが水路底に対して垂直となる瞬間(上側)，および，それから $\pi / 12 \mathrm{rad}$ 回転した瞬間 (下側)の 流速ベクトル図(縱軸は鉛直方向距離 $(\mathrm{m}) ，$ 横軸は水平方向距離 $(\mathrm{m}))$

現結果が得られたと考えられる.よって，羽根高さと 回転数の違いが水車設置による堰上げに及ぼす影響の 評価に対し，本研究で行ったMPS法による解析を適用 することは，妥当であると考えられる。

(5)今後は, 同一の実験結果を対象として空間解像度をよ り小さくした解析，もしくは，同一の空間解像度で規
模のより大きな実駼結果や実機を対象とした解析を行 い，実務設計一の適用に向けて，再現精度をさらに向 上させる検討を行う必要がある。

\section{参考文献}

1) 星野恵美子 : 那須野ヶ原用水における小水力発電事業につ 

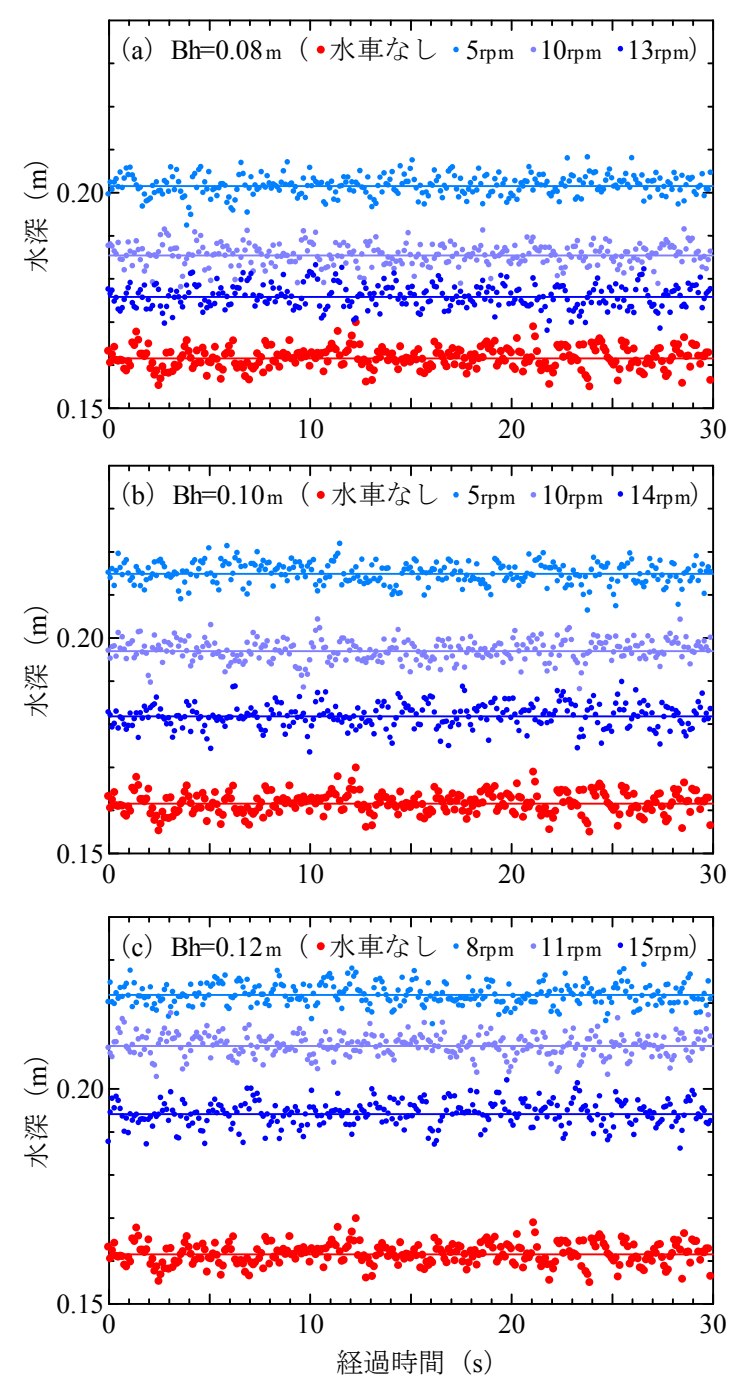

図-3 水車上流側の水深の経時変化

いて, 平成18年度 農業土木学会大会講演会 講演要旨集, pp.106-107, 2006. (http://soil.en.a.u-tokyo.ac.jp/jsidre/search/ PDFs/06/06S15-02.pdf)

2) 全国小水力利用推進協議会 編: 小水力発電がわかる本, オーム社, pp.90-91, 2012.

3) 後藤眞宏, 内田隆志, 加藤信介, 岡本将之, 大木啓司, 長 谷川大祐, 高木強治, 浪平篤 : 緩勾配水路における小水力発 電技術の開発，農業農村工学会誌，78(8)，pp.665-668，2010.

4) 池田敏彦, 飯尾昭一郎: エコ水車の開発と普及, 混相流, 25(3), pp.197-206, 2011.

5) 農林水産省農村振興局 : 土地改良事業計画設計基準及び運 用・解説 設計「水路工」, 農業農村工学会, pp.199-205, 2001.

6) 浪平篤, 後藤眞宏, 高木強治: 流し掛け水車の周辺の流れ のMPS法による数值解析, 土木学会論文集B1 (水工学), 69(4), pp.I 607-I 612, 2013.

7) 越塚誠一 : 粒子法, 丸善, 2005.

8) 後藤眞宏 : 流し掛け水車の水理特性と流水エネルギー変換 技術に関する研究, 農業工学研究所所報, 39, pp.161-196,

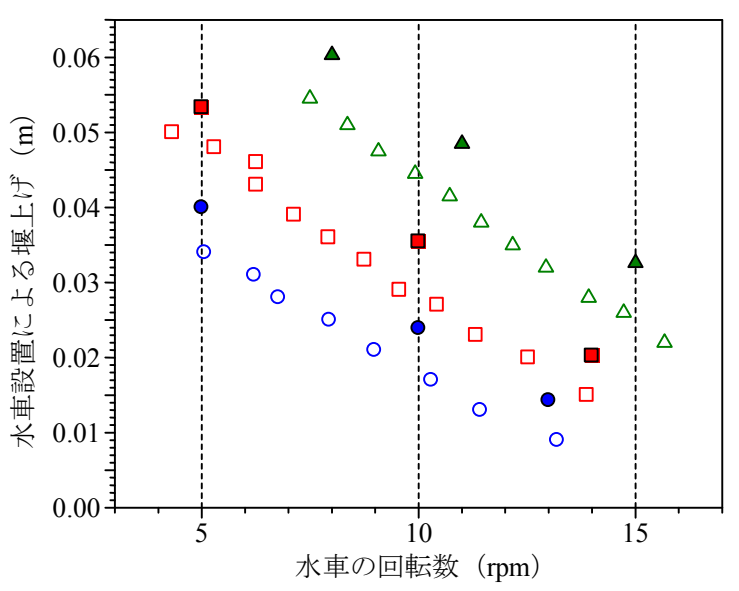

\begin{tabular}{|c|c|}
\hline ○ $\mathrm{Bh}=0.08 \mathrm{~m}$ の実験結果 ${ }^{8)}$ & - $\mathrm{Bh}=0.08 \mathrm{~m}$ の解析結果 \\
\hline$\square \mathrm{Bh}=0.10 \mathrm{~m}$ の実験結果 ${ }^{8)}$ & 口 $\mathrm{Bh}=0.10 \mathrm{~m}$ の角 \\
\hline$\triangle \mathrm{Bh}=0.12 \mathrm{~m}$ の実験結果 ${ }^{8)}$ & $\Delta \mathrm{Bh}=0.12 \mathrm{~m}$ の解析 \\
\hline
\end{tabular}

図-4＼cjkstart水車設置による堰上げ

2000. (http://agriknowledge.affrc.go.jp/RN/2010611099.pdf)

9) 五十里洋行 : 粒子法による自由表面流の数值解析とその水 工学への応用に関する研究，京都大学学位論文，2007.

10)中西裕二，藤井恒彰 : 粒子法によるペルトン水車バケット 内の流れの解析(第1報 相対軌跡を利用した1枚の回転バケッ 卜内の流れ)，日本機械学会論文集(B編)，73(728)，2007.

11)中西裕二，藤井恒彰，和智恒機 : 粒子法によるペルトン水 車バケット内の流れの解析(第2報 非設計点における流れと ランナ出力)，日本機械学会論文集(B編)，73(736)，2007.

12)土木学会海岸工学委員会数值波動水槽研究小委員会 : 数值 波動水槽一砕波波浪計算の深化と耐波設計の革新を目指して 一, pp.80-82, 2012.

13)Khayyer, A. and Gotoh, H. : Modified Moving Particle Semiimplicit methods for the prediction of $2 \mathrm{D}$ wave impact pressure, Coastal Engineering, 56(4), pp.419-440, 2009.

14)Khayyer, A. and Gotoh, H. : Enhancement of stability and accuracy of the moving particle semi-implicit method, Journal of Computational Physics, 230(8), pp.3093-3118, 2011.

15)近藤雅裕，越塚誠一：MPS法における不自然な数值振動の 抑制，日本計算工学会論文集，20080015，2008. (https:// www. jstage.jst.go.jp/article/jsces/2008/0/2008_0_20080015/_pdf)

16)Kondo, M. and Koshizuka, S. : Improvement of stability in moving particle semi-implicit method, International Journal for Numerical Methods in Fluids, 65, pp.638-654, 2011.

17)出水力 : 水車の技術史，思文閣出版， 1987.

18)Gotoh, H., Shibahara, T., Sakai, T. : Sub-particle-scale turbulence model for the MPS method - Lagrangian flow model for hydraulic engineering -, Computational Fluid Dynamics Journal, 9-4, pp.339$347,2001$.

(2013. 9. 30受付) 